\title{
Differences in the subgingival microbial population of chronic periodontitis in subjects with and without Type 2 Diabetes Mellitus - A systematic review
}

\author{
Linda Sun Liu ${ }^{1}$, Nikolaos Gkranias ${ }^{2}$, Bruna Farias ${ }^{3}$, Dave Spratt ${ }^{4}$, Nikolaos Donos ${ }^{2}$. \\ ${ }^{1}$ Periodontology Unit, UCL Eastman Dental Institute, London, UK \\ ${ }^{2}$ Centre for Oral Clinical Research, Institute of Dentistry, Barts \& The London School of Medicine \\ and Dentistry, QMUL, London, UK. \\ ${ }^{3}$ Postgraduate Department, Federal University of Pernambuco, Recife -Brazil. \\ ${ }^{4}$ Microbiology Department, UCL Eastman Dental Institute, London, UK.
}

Corresponding author: Professor Nikolaos Donos: Centre for Oral Clinical Research, Institute of Dentistry, Barts \& The London School of Medicine \& Dentistry, Queen Mary University of London (QMUL), Turner Street, London E1 2AD, UK

Email: n.donos@qmul.ac.uk (can be published), Phone: +44 2078823063

\section{Abstract}

Objectives: The purpose of this systematic review was to evaluate the available evidence in the literature in regards to the subgingival microbial population of chronic periodontitis in subjects with Type 2 Diabetes Mellitus (T2DM+PD) compared to non-diabetic subjects (NDM+PD).

Materials and Methods: A literature search was conducted at Ovid MEDLINE and EMBASE database from 1980 to 2016, supplemented by hand searching as needed. Studies presenting with at least one of the primary outcomes (presence of any subgingival microorganisms, proportion and/or the amount of any subgingival plaque bacteria in T2DM+PD versus NDM+PD) were included. Screening, data extraction and quality assessment were conducted independently and in duplicate.

Results: From 611 citations, 19 full-text papers were screened and 11 articles were included for critical appraisal by both reviewers. Some evidence of a difference in the microbial profile between chronic PD subjects with and without T2DM was identified. The strength of evidence is strongest in Tannerella forthysia (T.forsythia) which was reported to be less frequent in the diabetic 
(T2DM+PD) group in five of the studies, followed by a weaker strength of evidence for other periodontal pathogens such as Porphyromonas gingivalis (P. gingivalis) and Aggregatibacter actinomycetemcomitans (A. actinomycetemcomitans), which were also found less frequent in the diabetic (T2DM+PD) group .

Conclusion: Only few studies have compared T2DM+PD with NDM+PD. It is therefore, strongly recommended that further studies which include four distinct groups of participants (NDM+PD, T2DM+PD, NDM+NPD, T2DM+NPD) instead of using intra-subject comparisons between healthy and diseased sites of the same subjects.

Clinical Relevance: Differences in bacterial populations of T2DM+PD in comparison to $\mathrm{NDM}+\mathrm{PD}$ subjects may indicate the need of different protocols for the treatment of the diabetic patients with periodontal disease.

\section{Introduction}

Periodontitis (PD) is defined as an inflammatory disease of the periodontium, caused by the dental bacterial plaque that results in loss of connective tissue attachment, loss of alveolar bone support and periodontal pocket formation $[1,2]$.

The bacteria that have been implicated in the PD have been extensively researched [3] and have been classified by Socransky and co-workers into different colour-coded complexes according to the stages of their colonisation on the tooth surface [4]. Of these groups, the red complex, which includes Porphyromonas gingivalis (P.gingivalis), Tannerella forsythia (T.forsythia) and Treponema denticola (T.denticola), has been positively correlated to probing pocket depth (PPD) extent and disease severity [4]; although several studies have found PD present even in the absence of these bacteria [5]. At the same time, PD extent and disease severity are defined by the host response to the same bacterial exposure, which can differ among individuals and has been suggested to be affected, amongst others, by the differential expression of the different genes and pro-inflammatory mediators [6-10].

Regardless of the individual susceptibility to PD, other systemic diseases like diabetes mellitus (DM) can affect the manifestation of PD [11, 61]. The relationship between PD and DM has been established by several longitudinal studies $[11,12]$. An 11-fold increase in the risk of PD has been observed in uncontrolled type 2 diabetes mellitus (T2DM) patients in a 2-year longitudinal study that compared T2DM to non-diabetic (NDM) subjects [13]. This has been partially attributed to an altered immune response, metabolic and healing potential in the presence of DM partially attributed to the mechanism of advanced glycation end-products $[14,62]$. However, it still remains unclear if DM has also an effect on the subgingival bacterial population in PD [15]. It is known that higher gingival crevicular fluid (GCF) glucose concentrations can be found in T2DM subjects when compared to NDM controls [16]. This, in theory, can prompt the occurrence of fermentation, which would generate sufficient energy for the growth requirements of anaerobic bacteria [17]. Furthermore, the metabolic by-products of glucose such as acid and alcohols have the ability of altering the surrounding environment and thereby further facilitate the growth of fermenting 
bacteria leading to a shift of the microbial population [18]. Consequently, a different bacterial population could be expected in such a glucose-rich environment. It is therefore significant that a saccharolytic species like Capnocytophaga have been found in higher concentrations in T2DM+PD patients when compared to NDM+PD patients [19]. In regards to the rest of the periodontal bacteria there are studies that have suggested limited differences in the subgingival microbiota between $\mathrm{DM}+\mathrm{PD}$ and NDM+PD patients; however, most studies of this kind have been done more than two decades ago and therefore, present with several limitations including bacterial identification methods [20, 21]. With the advent of new molecular identification methods, it has now become possible to identify more cultivable taxa using the polymerase chain reaction (PCR) technique coupled with gene sequencing [22]. In particular, 16S rRNA sequence analysis allows the identification of uncultivable taxa as the 16S rRNA gene is found in all bacteria and archaea [23] and contains a highly conserved region enabling sequencing and taxa identification to be carried out easily [24].

\section{Aims and Objectives}

The purpose of this systematic review was to evaluate the evidence available in the literature in regards to the microbial population in T2DM+PD compared to NDM+PD subjects.

\section{Materials and Methods}

The focused question addressed was: "Which bacteria are different between the microbial population in PD in the presence or absence of T2DM?"

Our null hypothesis was "There is no difference between the microbial population in PD in the presence or absence of T2DM".

A search of Ovid MEDLINE and EMBASE databases was conducted for the period between the years 1980 and 2016. In addition, reference lists of all included articles and relevant review publications were manually screened for studies that had not been identified by the electronic search. Furthermore, hand-searching was carried out on the dental journals most likely to publish periodontal clinical studies between the years 1980 and 2016.

The search strategy for MEDLINE and EMBASE used a combination MeSH terms and text words. The initial electronic search strategies were formulated for MEDLINE and later modified as appropriate for EMBASE. The details of the electronic search strategy were as follows:

Population: "PERIODONTAL DISEASE” OR “Periodont\$” OR “Gum disease\$”.

Exposure: "DIABETES MELLITUS" OR "Diabet\$”.

Outcome: "BACTERIUM" OR "MICROORGANISM" OR “TOOTH PLAQUE" OR “BIOFILMS” OR “Microorganism\$” OR “Microbe\$” OR “Biofilm\$” OR "Plaque\$”.

Limit: "HUMAN" AND "ENGLISH”.

The search was conducted as follows: Population AND Exposure AND outcome AND Limit. 


\section{Inclusion/Exclusion criteria}

Human studies in patients with chronic periodontitis or relevant previous diagnoses with or without T2DM, including mixed Type 1 and Type $2 \mathrm{DM}$, presenting data on microbial population were considered eligible. Only studies in English, including at least 10 patients (5 T2DM+PD, 5 $\mathrm{NDM}+\mathrm{PD}$ ), with a minimum of 5 teeth per subject, $\geq 16$ years old, nor any intake of antibiotics within the last 3 months prior to bacteriological sampling, and no history of immune-compromising disease were included.

Studies presenting aggressive periodontitis or relevant previous classification diagnoses, other types of diabetes, such as gestational diabetes and type 1 diabetes, and experimental studies were excluded.

Outcome measures

- The presence of any subgingival microorganisms in $\mathrm{T} 2 \mathrm{DM}+\mathrm{PD}$ vs $\mathrm{NDM}+\mathrm{PD}$.

- The proportion and/or the amount of any subgingival plaque bacteria in T2DM+PD versus $\mathrm{NDM}+\mathrm{PD}$.

\section{Screening methods and data extraction}

The studies were selected with a two-stage screening process that was carried out by two independent reviewers (L.S.L and B.F.). Disagreements about inclusion or exclusion of a study were resolved by consensus and when necessary a third reviewer (N.D.) was consulted. In the first stage, screening of titles and abstracts was carried out to eliminate irrelevant articles and those that did not meet the inclusion criteria established by this study. At the second stage, following proof reading of the full text, the study eligibility was verified independently by both reviewers and the data extraction and quality assessment were performed for the included studies. Furthermore, forward reference searching was also performed for the included studies, but this did not yield any further studies.

The level of agreement between the two reviewers was calculated using Kappa statistics for the first- and second-stage screening.

\section{Methodology Quality Assessment}

The methodological quality of included studies was assessed, utilising the tools described in the Cochrane Handbook for Systematic Reviews of Interventions 5.1.0 [25]. As different types of studies were included in this systematic review, both the Cochrane assessment tool and the Newcastle-Ottawa Scale (NOS) were used to assess the quality of the studies according to the study type [26].

\section{Results}

The initial search resulted in 611 potentially eligible articles. Following the first-stage of title and abstract screening, 592 papers were excluded, and 19 articles qualified for full-text screening by 
both reviewers. Following full text screening, 8 further articles were excluded due to not meeting the inclusion criteria in regards to comparison groups and therefore, 11 articles were finally selected for critical appraisal by both reviewers. A summary of the systematic review workflow is presented in Figure 1.

The kappa value for inter-reviewer agreement was 0.76 at title and abstract screening and 0.62 at full-text reading, showing a substantial agreement between the reviewers. The weighted kappa scores were 0.84 and 0.72 respectively.

\section{Study and Patient Characteristics}

The 11 studies included in this review consisted of 10 case-control studies [19, 21, 27, 28, 29, 30, 31, 32, 33, 34] and 1 controlled clinical trial [35]. All 11 included articles presented microbiological results before periodontal treatment, and only 1 article also presented the microbial population after non-surgical treatment [35].

The included controlled clinical trial [35], compared the microbiological effect of non-surgical periodontal therapy at baseline, 2 weeks after supragingival and 4 months after subgingival therapy in T2DM+PD and NDM+PD groups. Two out of the eleven studies [19, 34] stated the ethnicity of the study participants while the remaining studies did not provide relevant details. There was an average number of approximately 50 patients involved in three studies [19, 21, 33], while four further studies included over 60 patients each [27, 28, 30, 31]. The remaining studies had around 20-30 patients included [29, 32, 34]. The age range of the patients included was mostly between 30 to 60 years of age.

In most studies, the patients' periodontal status was classified using the Armitage (1999) classification [27-29, 32] or similar criteria [33-35]. However, in four studies [19, 21, 30, 31] the definition of the periodontal disease was not reported clearly. The classification employed for the DM diagnoses was clearly indicated in only three studies [27, 28, 30]. In one study [35], both T1DM and T2DM patients were included without stratification and thus the microbial results reflected on both types of diabetes mellitus. The smoking habits of the patients included were not identified in 5 of the studies $[21,28,29,31,32]$. These data are summarised in Table 1.

Regarding the status of DM control, in 5 articles it was not clear [21, 28, 30, 33, 34]. Four articles reported to have controlled and non-controlled DM in the same sample [19, 27, 31, 35]. One article had controlled DM only [29] and one article had only non-controlled DM [32].

Microbiological Analysis

Outcomes

There was a lack of homogeneity between the species of bacteria investigated in all studies. Different methods were used to determine the proportion of bacteria and different definitions of PD and DM were applied in the included studies (Tables 1-3). 
The outcomes reported in most studies [21, 27-29, 32, 34, 35] are in the format of percentage of bacteria of interest, recovered from subgingival plaque samples in NDM+PD groups versus those of DM+PD groups. A different method of grouping was carried out in one study [30], where the prevalence of bacteria was compared in diseased and healthy sites of the diabetic and non-diabetic subjects with periodontitis. The number and percentage of cultivable bacterial isolates, the percentage of positive sites and positive patients were provided in one study [21]. In another study [27], the percentages of subjects colonised with bacteria of interest were reported in the diabetic and the non-diabetic group without identification of the presence of the periodontal disease in each subject. Another study [28] reported the percentage distribution of different genotypes of $P$. gingivalis in NDM+NPD no disease group, NDM+PD group and T2DM+PD group with data available as subdivision of the genotypes.

Cloning and traditional sequencing were done to analyse the distribution of the percentages of clones containing different bacteria in T2DM+PD and NDM+PD samples in one study [32]. Another study [34] applied next-generation 454 pyrosequencing on T2DM+PD, NDM+PD, T2DM+NPD and NDM+NPD samples, which reported the outcome as species-level operational taxonomic unit (OTU) which is defined by a sequence similarity threshold such as $\geq 97 \%$ for a 'species'-level phylotype. The relative abundances of the OTUs in signature bacteria were reported and compared.

\section{Key Findings}

A significant lower proportion [29, 32, 34] and frequency [27, 30] of T. forsythia in T2DM+PD group versus NDM+PD groups has been reported. Out of the 6 studies [27, 29, 30, 32-34] that reported $T$. forsythia, four studies had an agreement on the presence of lower percentage of $T$. forsythia in T2DM+PD in comparison to NDM+PD group.

Five studies [27, 29, 30, 32, 35] investigated A. actinomycetemcomitans and $P$. gingivalis. One study [27] reported that the proportion of $P$. gingivalis was higher in NDM compared to that of T2DM group. There was less conclusive evidence on the report of $P$. gingivalis in other studies. In one study [29], A. actinomycetemcomitans and P. gingivalis did not have statistically significant differences when comparing the T2DM+PD and NDM+PD groups. On the other hand, one study [30] showed higher frequency of A. actinomycetemcomitans and P. gingivalis in T2DM+PD.

A study [32] that was conducted in Brazil reported several genera with higher detection frequency in the NDM+PD group: Porphyromonas, Filifactor, Eubacterium, Synergistetes, Tannerella and Treponema $(\mathrm{p}<0.05)$. In addition, in the T2DM+PD group of this study, genera such as TM7, Aggregatibacter, Neisseria, Gemella, Eikenella, Selenomonas, Actinomyces, Capnocytophaga, Fusobacterium, Veillonella and Streptococcus genera have been found at higher detection frequency than the other genera $(\mathrm{p}<0.05)$.

Another study [34] that was conducted in China, employed next generation sequencing and reported results of microbiota among NDM+PD versus NDM+NPD and T2DM+NPD versus 
T2DM+PD groups. The OTUs that had their relative abundance increased in T2DM+PD were the family of Propionibacteriaceae, Capnocytophaga sputigena, Tannerella forsythia and the order Burkholderiales. Those that had relative abundance decreased in T2DM+PD were the family of Prevotellaceae and Prevotella tannerae [34]. The T2DM+PD associated bacteria include Porphyromonas gingivalis, the genus of Leptotrichia, Treponema medium, the order of Bacteroidales, Tannerella forsythia, the family of Synergistaceae, Porphyromonas endodontalis, unclassified OTU0056 and Filifactor alocis [34].

\section{Methodological Qualities of the Studies Included}

There was a mutual agreement amongst reviewers that all studies had potential for selection bias as they may not be representative of the DM or PD disease populations. In most studies the case definition was adequate, however, the reporting of which criteria used to diagnose diabetes or periodontitis was inadequate despite their detailed description [19, 31, 33]. As for the selection of controls, all studies recruited their patients from a hospital environment except for three studies $[21,27,31]$ where no description was given. Two studies scored highest in the comparability section $[19,31]$ as both studies accounted for the confounding factors, whereas such statement is often unclear in other studies. Whether the disease status was blinded to the investigators at the time of experiments remains questionable in five of the studies [21, 28, 31,34], while the remaining studies provided clear statements. (Appendix Table A). Three out of 11 studies were considered to be of higher quality $[19,30,32]$, followed by five studies of lesser quality [21, 27, 33-35] then 3 studies of the least quality $[28,29,31]$ based on the various factors of study design.

\section{Strength of Evidence}

Although most of the studies reviewed are case-control studies, differences among them in the case definitions, sources of patient population, experimental nature as well as outcome measurements renders it challenging to draw any overall definitive conclusions by aggregating their results. In terms of the case definitions, various methods were used to define the severity of periodontal disease and the definition of diabetes used was not always mentioned. The implication of this is that the grouping of mild, moderate or severe periodontitis among these studies may vary due to different classification systems used. However, the problem with case definitions in diabetes may be less influential on the strength of evidence as most misclassification occurs in young adults [37] and the studies included in this review recruited older adults. For instance, only one study [21] out of the 11 studies included the lower age limit of 17 years old, which potentially poses the risk of a misclassification of diabetes mellitus as type II. However, the rest of the studies included patients of similar age range.

Sources of recruitment were mostly reported as deriving from university dental hospitals and there was no involvement of community clinics, thus they represent a narrow-range population. Most studies mentioned specific inclusion or exclusion criteria and sometimes both, which represents a strict selection of patient characteristics within the recruited population. Confounding factors were not reported in all studies, and only one study [19] stated adjustments for confounding factors in 
the statistical analysis. There was no mention of other confounding factors in these studies other than the smoking status, which has been known to be a risk factor of periodontal disease. In terms of grouping of the diseased individuals, some studies grouped both type one and two diabetes into the diseased group when compare to the non-diabetic groups. One study [30] identified both healthy and diseased sites in both diabetic and non-diabetic groups but failed to clearly differentiate between the groups in the reporting of the microbiological results. The majority of the studies identified in this systematic review focused on one or more of the periodontal pathogens especially the red complex, moreover, reported the results as the percentage population colonised with such bacteria of interest.

\section{Potential Bias in the Review Process}

Despite the language restrictions being a potential source of publication bias, in this review unpublished studies were also searched for, although none were identified. All review processes were independent with duplicate screening for study eligibility.

\section{Discussion/Limitations and Conclusion}

This systematic review attempts to describe the differences in subgingival microbial population of chronic periodontitis between subjects with Type 2 Diabetes Mellitus (T2DM+PD) and nondiabetic (NDM+PD) subjects.

A lower detection frequency of $P$. gingivalis, A. actinomycetemcomitans, $T$. forsythia in T2DM+PD as opposed to NDM+PD subjects was reported in a few studies [27, 28, 35]. In one study [28], DM was found to have no prominent effect on the fimA genotype of $P$. gingivalis, which is consistent with the results reported by another study [29] where no differences were shown between T2DM+PD and NDM +PD groups for $P$. gingivalis. Furthermore, the latter study [29] reported an increase in the percentage of sites colonised with A. actinomycetemcomitans in $\mathrm{NDM}+\mathrm{PD}$ as opposed to T2DM+PD patients. It is important to emphasise that the trend of $A$. actinomycetemcomitans and $P$. gingivalis is consistent in all studies [27, 29, 35], whereas two studies agreed in the finding of $T$. forsythia being found less prevalent in T2DM+PD versus NDM+PD [27, 29]. In general, there were minor differences in the frequency or proportion of $P$. gingivalis between the T2DM and NDM groups, with weak evidence suggesting a decreasing trend of $P$. gingivalis in the NDM group [27, 28, 35]. The evidence of the decreasing trend of $T$. forsythia in the NDM group remains weak, but with more studies in agreement with this outcome [27, 29, $30,32,34]$.

There was a mixture of the geographic regions where the studies were conducted, nevertheless, it would have been preferable to have a blend of studies from a more diverse racial background to observe a true universal effect. In addition, only one study [19] among the 11 studies stated the ethnicity of the patients, which has been accounted for as a variable of periodontal diseases [38]. The evidence provided by either case-control studies or cross-sectional studies would remain limited for the investigation of the microbial community between DM and NDM. Longitudinal 
studies where the report of the subgingival microbiota after the return to health following therapy, as well as that in health and disease are required to strengthen the evidence of the effect of diabetes on the subgingival microbiota [39].

Masking of assessors was not always stated; however, most samples were collected prior to the experiments taking place and such problem was less influential on the outcome. The type of experimental techniques used, such as culturing method, PCR, BANA analysis or DNA-DNA hybridisation technique, all have different start and end points. If any DNA extraction were to be carried out, the timing, the storage method of the DNA or the method itself could all vary within this discipline [40], which could further increase the variability of the results in these studies. In terms of the collection of subgingival plaque samples, most studies used curettes to collect the bacterial samples with fewer studies using paper points. As it has been suggested previously, the usage of different subgingival plaque collection methods do not generally have a significant effect on the microbiological outcome [41] and such factor is considered less influential on the strength of evidence. It is not clear if most of the studies performed site-based rather than subject-based analysis as the latter method could inflate the statistical power thereby misleading the results [42]. Only four of the studies stated that the subgingival plaque samples collected from different sites from the same patient were pooled for microbiological analysis [29, 32, 33, 35].

The variability of methodologies used in the studies reviewed did not permit us to conduct a metaanalysis or attempt to perform direct comparisons between the results presented. For instance, there were differences between studies with case definition, diagnostic criteria and different microbiological analysis as well as experimental methods. In addition, most studies focused on one or a few of the commonly investigated periodontal pathogens such as the different fim A genotype of $P$. gingivalis, . forsythia and A. actinomycetemcomitans using various detection techniques, while no studies focused on the entire microbial ecology using more persuasive tools such as nextgeneration sequencing. With the use of such next-generation sequencing, one would be able to identify any shift of the microbial population between diseased and healthy group more accurately while at the same time, being able to identify any difference in the bacteria in a less prejudiced scope [43].

Quantitative PCR (qPCR) used in a study [33] allows absolute or relative quantification of the counts and proportion of targeted bacteria, which is less labour-intensive than the culturing technique [44]. There has been report on the discrepancy of the outcome of qPCR and the culturing technique, mainly due to qPCR including also the presence of dead bacteria [45]. The outcome of the same samples using qPCR or 454 pyrosequencing have similar patterns, but with discrepancies mainly because qPCR targets a specific species while the NGS reports at a higher taxonomic genus level [39]. The targeted techniques such as qPCR and culturing remain advantageous in providing information on pathogenicity of specific bacteria, however, their shortcomings of the lack of a broader picture of the microbial community render these techniques less beneficial in investigating the shift of the microbiome between case and controls [39, 45-47]. In addition, DNA-DNA hybridisation technique used in one of the studies [30] helped to identify the presence of bacteria 
between groups. However, as the virulence of a bacteria that remained similar between the group may change more dramatically in one group versus another resulting in increased pathogenicity, the investigation on simply the presence or absence of bacteria may be inadequate [48] and this would be an issue with all technology used in the studies reported too.

As uncultured taxa constitute also a large part of the diseased microbiome [39, 49-51], the use of sequencing techniques enables one to obtain a broader overview of the microbial community between health and disease while providing a more efficient and DNA-saving method [45, 52]. Inter-individual variation in the subgingival microbiome of periodontitis and health or smokers versus non-smokers have been identified, with some of the common periodontal pathogens showing low relative abundance in disease further demonstrating the limited information available from the targeted technique and this may explain the discrepancy of outcomes between studies in addition to other factors $[39,53]$.

Although sequencing allows observation of a broader microbiological picture as opposed to specific bacteria, different library preparation, sequencing platforms, 16s rRNA gene regions targeted and bioinformatics pipeline all complicates the comparisons of microbial community [54]. In one of the studies [32] for example, 16s rDNA Sanger sequencing was conducted, with the traditional cloning and sequencing method being a source of potential bias to the study. Another study [34] that was conducted more recently utilised 16s rDNA pyrosequencing to compare the microbiota and provided results with a higher level of evidence confirming some of the previous reported results.

\section{Recommendations for Future Research}

As the research question addresses two different diseases it is important to consider the different confounding factors of each disease as well as potential problems with misclassification. Therefore, factors like age of the participants [55] and representative mixture of subjects in terms of ethnicity, geographic regions, socio-economic status [56-58] should be employed.

When analysing un-pooled subgingival plaque samples, it is recommended that both site-specific and subject-specific analysis are carried-out using methods such as multilevel modelling [19]. Furthermore, specifying in the material and methods whether the microbial samples have been pooled together from multiple sites or not, would enhance the understanding of the quality of the study, as a site-based and a subject-based study are founded on different statistical nature [59].

In regards to the analysis method next-generation sequencing is proposed as the most ideal method for such studies to identify the microbial shift. However, should PCR or other procedures be carried out, detailed statements of the type of DNA extraction, its timing and under which conditions it took place should be accurately reported as it is important for the quality of the yielding DNA [60]. Moreover, next generation sequencing could allow the investigation of not previously targeted bacteria in the presence of DM and PD, cultivable or uncultivable. This can lead to new insight in the microbial interactions [43] [32]. 
As shown in this systematic review, only few of the studies available have compared patients with diabetes and periodontitis versus non-diabetic-periodontitis subjects. It is therefore, strongly recommended that future studies include four distinct groups of participants (NDM+PD, T2DM+PD, NDM+NPD, T2DM+NPD) instead of using intra-subject comparisons between healthy and diseased sites of the same subjects.

\section{Compliance with Ethical Standards}

Conflict of Interest: The authors declare that they have no conflict of interest.

Funding: The work was supported by the Department of Periodontology, UCL Eastman Dental Institute, London, UK.

Ethical approval: This article does not contain any studies with human participants or animals performed by any of the authors. For this type of study, ethical approval is not required.

Informed consent: For this type of study, formal consent is not required.

\section{References}

1. Jenkinson HF, Dymock D (1999) The microbiology of periodontal disease. Dent Update 26:191.

2. Van Der Velden U (2005) Purpose and problems of periodontal disease classification. Periodontol 2000 39:13-21. doi: 10.1111/j.1600-0757.2005.00127.x

3. Pérez-Chaparro PJ, Gonçalves C, Figueiredo LC, et al (2014) Newly identified pathogens associated with periodontitis: a systematic review. J Dent Res 93:846-58. doi: $10.1177 / 0022034514542468$

4. Dzink JL, Socransky SS, Haffajee AD (1988) The predominant cultivable microbiota of active and inactive lesions of destructive periodontal diseases. J Clin Periodontol 15:31623.

5. Socransky SS, Haffajee AD (2005) Periodontal microbial ecology. Periodontol 2000 38:135-187. doi: 10.1111/j.1600-0757.2005.00107.x

6. Socransky SS, Haffajee AD, Smith C, Duff GW (2000) Microbiological parameters associated with IL-1 gene polymorphisms in periodontitis patients. J Clin Periodontol 
27:810-818. doi: 10.1034/j.1600-051x.2000.027011810.x

7. Trevilatto PC, Scarel-Caminaga RM, de Brito RB, et al (2003) Polymorphism at position174 of IL-6 gene is associated with susceptibility to chronic periodontitis in a Caucasian Brazilian population. J Clin Periodontol 30:438-442. doi: 10.1034/j.1600051X.2003.20016.x

8. Babel N, Cherepnev G, Babel D, et al (2006) Analysis of tumor necrosis factor-alpha, transforming growth factor-beta, interleukin-10, IL-6, and interferon-gamma gene polymorphisms in patients with chronic periodontitis. J Periodontol 77:1978-83. doi: 10.1902/jop.2006.050315

9. Toomes C, James J, Wood AJ, et al (1999) Loss-of-function mutations in the cathepsin C gene result in periodontal disease and palmoplantar keratosis. Nat Genet 23:421-424. doi: $10.1038 / 70525$

10. Nibali L, Donos N, Henderson B (2009) Periodontal infectogenomics. J Med Microbiol 58:1269-74. doi: 10.1099/jmm.0.012021-0

11. Grossi SG, Genco RJ (1998) Periodontal Disease and Diabetes Mellitus: A Two-Way Relationship*. Ann Periodontol 3:51-61.

12. Seppälä B, Seppälä M, Ainamo J (1993) A longitudinal study on insulin-dependent diabetes mellitus and periodontal disease. J Clin Periodontol 20:161-5.

13. Taylor GW, Burt BA, Becker MP, et al (1998) Non-insulin dependent diabetes mellitus and alveolar bone loss progression over 2 years. J Periodontol 69:76-83. doi: 10.1902/jop.1998.69.1.76

14. Lalla E, Papapanou PN (2011) Diabetes mellitus and periodontitis: a tale of two common interrelated diseases. Nat Rev Endocrinol 7:738-48.

15. Mealey BL, Oates TW (2006) Diabetes Mellitus and Periodontal Diseases. J Periodontol 77:1289-1303. doi: 10.1902/jop.2006.050459

16. Ficara AJ, Levin MP, Grower MF, Kramer GD (1975) A comparison of the glucose and protein content of gingival fluid from diabetics and nondiabetics. J Periodontal Res 10:171-175. doi: 10.1111/j.1600-0765.1975.tb00022.x

17. Anestis M (2006) AP Biology, 2nd ed. McGraw-Hill Professional

18. Walker AW, Duncan SH, McWilliam Leitch EC, et al (2005) pH and peptide supply can radically alter bacterial populations and short-chain fatty acid ratios within microbial communities from the human colon. Appl Environ Microbiol 71:3692-700. doi: 10.1128/AEM.71.7.3692-3700.2005

19. Ciantar M, Gilthorpe MS, Hurel S, et al (2005) Capnocytophaga spp. in periodontitis patients manifesting diabetes mellitus. J Periodontol 76:194-203. doi: 10.1902/jop.2005.76.2.194 
20. Sastrowijoto SH, Hillemans P, van Steenbergen TJ, et al (1989) Periodontal condition and microbiology of healthy and diseased periodontal pockets in type 1 diabetes mellitus patients. J Clin Periodontol 16:316-322.

21. Zambon JJ, Reynolds H, Fisher JG, et al (1988) Microbiological and immunological studies of adult periodontitis in patients with noninsulin-dependent diabetes mellitus. J Periodontol 59:23-31.

22. Spratt D (2004) Significance of bacterial identification by molecular biology methods. Endod Top 9:5-14. doi: 10.1111/j.1601-1546.2004.00106.x

23. Weisburg WG, Barns SM, Pelletier DA, Lane DJ (1991) 16S ribosomal DNA amplification for phylogenetic study. J Bacteriol 173:697-703.

24. Coenye T, Vandamme P (2003) Intragenomic heterogeneity between multiple 16S ribosomal RNA operons in sequenced bacterial genomes. FEMS Microbiol Lett 228:4549. doi: 10.1016/S0378-1097(03)00717-1

25. Higgins GS (editors). (2011) Cochrane Handbook for Systematic Reviews of Interventions Version 5.1.0 [updated March 2011]. The Cochrane Collaboration. In: Cochrane Collab. 2011. http://www.cochrane.org/training/cochrane-handbook. Accessed 16 Apr 2012

26. Wells G, Shea B, O'Connell D, et al (2000) The Newcastle-Ottawa Scale (NOS) for assessing Available, quality if nonrandomized studies in meta-analyses.

27. Collin HL, Uusitupa M, Niskanen L, et al (1998) Periodontal findings in elderly patients with non-insulin dependent diabetes mellitus. J Periodontol 69:962-6.

28. Davila-Perez C, Amano A, Alpuche-Solis AG, et al (2007) Distribution of genotypes of Porphyromonas gingivalis in type 2 diabetic patients with periodontitis in Mexico. J Clin Periodontol 34:25-30. doi: 10.1111/j.1600-051X.2006.01011.x

29. Sardi JCO, Duque C, Camargo GACG, et al (2011) Periodontal conditions and prevalence of putative periodontopathogens and Candida spp. in insulin-dependent type 2 diabetic and non-diabetic patients with chronic periodontitis--a pilot study. Arch Oral Biol 56:1098105. doi: 10.1016/j.archoralbio.2011.03.017

30. Ebersole JL, Holt SC, Hansard R, Novak MJ (2008) Microbiologic and immunologic characteristics of periodontal disease in Hispanic americans with type 2 diabetes. J Periodontol 79:637-46. doi: 10.1902/jop.2008.070455

31. Novaes AB, Gonzalez Gutierrez F, Grisi MF (1997) Periodontal disease progression in type II non-insulin-dependent diabetes mellitus patients (NIDDM). Part II-Microbiological analysis using the BANA test. Braz Dent J 8:27-33.

32. Casarin RC V, Barbagallo A, Meulman T, et al (2013) Subgingival biodiversity in subjects with uncontrolled type-2 diabetes and chronic periodontitis. J Periodontal Res 48:30-6. doi: 10.1111/j.1600-0765.2012.01498.x 
33. Field CA, Gidley MD, Preshaw PM, Jakubovics N (2012) Investigation and quantification of key periodontal pathogens in patients with type 2 diabetes. J Periodontal Res 47:470-8. doi: 10.1111/j.1600-0765.2011.01455.x

34. Zhou M, Rong R, Munro D, et al (2013) Investigation of the effect of type 2 diabetes mellitus on subgingival plaque microbiota by high-throughput 16S rDNA pyrosequencing. PLoS One 8:e61516. doi: 10.1371/journal.pone.0061516

35. Christgau M, Palitzsch KD, Schmalz G, et al (1998) Healing response to non-surgical periodontal therapy in patients with diabetes mellitus: clinical, microbiological, and immunologic results. J Clin Periodontol 25:112-24.

36. Armitage GC (1999) Development of a classification system for periodontal diseases and conditions. Ann Periodontol 4:1-6. doi: 10.1902/annals.1999.4.1.1

37. Stone MA, Camosso-Stefinovic J, Wilkinson J, et al (2010) Incorrect and incomplete coding and classification of diabetes: a systematic review. Diabet Med 27:491-7. doi: 10.1111/j.1464-5491.2009.02920.x

38. Rylev M, Kilian M (2008) Prevalence and distribution of principal periodontal pathogens worldwide. J Clin Periodontol 35:346-61. doi: 10.1111/j.1600-051X.2008.01280.x

39. Bizzarro S, Loos BG, Laine ML, et al (2013) Subgingival microbiome in smokers and nonsmokers in periodontitis: an exploratory study using traditional targeted techniques and a next-generation sequencing. J Clin Periodontol 40:483-92. doi: 10.1111/jcpe.12087

40. Smith S, Morin PA (2005) Optimal storage conditions for highly dilute DNA samples: a role for trehalose as a preserving agent. J Forensic Sci 50:1101-8.

41. Jervøe-Storm P-M, Alahdab H, Koltzscher M, et al (2007) Comparison of curet and paper point sampling of subgingival bacteria as analyzed by real-time polymerase chain reaction. J Periodontol 78:909-17. doi: 10.1902/jop.2007.060218

42. Yang MCK, Marks RG, Clark WB, Magnusson I (1991) Evaluation of statistical methods for monitoring periodontal disease. Stat Med 10:1089-1097. doi: 10.1002/sim.4780100709

43. Abusleme L, Dupuy AK, Dutzan N, et al (2013) The subgingival microbiome in health and periodontitis and its relationship with community biomass and inflammation. ISME J 7:1016-25. doi: 10.1038/ismej.2012.174

44. Saunders NA, Martin A. Lee (2009) Real-Time PCR: Current Technology and Applications.

45. Boutaga K, van Winkelhoff AJ, Vandenbroucke-Grauls CMJE, Savelkoul PHM (2005) Periodontal pathogens: a quantitative comparison of anaerobic culture and real-time PCR. FEMS Immunol Med Microbiol 45:191-9. doi: 10.1016/j.femsim.2005.03.011

46. Boutaga K, van Winkelhoff AJ, Vandenbroucke-Grauls CMJE, Savelkoul PHM (2003) Comparison of real-time PCR and culture for detection of Porphyromonas gingivalis in 
subgingival plaque samples. J Clin Microbiol 41:4950-4.

47. Boutaga K, van Winkelhoff AJ, Vandenbroucke-Grauls CMJE, Savelkoul PHM (2006) The additional value of real-time PCR in the quantitative detection of periodontal pathogens. J Clin Periodontol 33:427-33. doi: 10.1111/j.1600-051X.2006.00925.x

48. Szafrański SP, Deng Z-L, Tomasch J, et al (2015) Functional biomarkers for chronic periodontitis and insights into the roles of Prevotella nigrescens and Fusobacterium nucleatum; a metatranscriptome analysis. npj Biofilms Microbiomes 1:15017. doi: 10.1038/npjbiofilms.2015.17

49. Vartoukian SR, Palmer RM, Wade WG (2010) Cultivation of a Synergistetes strain representing a previously uncultivated lineage. Environ Microbiol 12:916-28. doi: 10.1111/j.1462-2920.2009.02135.x

50. Griffen AL, Beall CJ, Campbell JH, et al (2012) Distinct and complex bacterial profiles in human periodontitis and health revealed by $16 \mathrm{~S}$ pyrosequencing. ISME J 6:1176-85. doi: 10.1038/ismej.2011.191

51. Kumar PS, Griffen AL, Moeschberger ML, Leys EJ (2005) Identification of candidate periodontal pathogens and beneficial species by quantitative $16 \mathrm{~S}$ clonal analysis. J Clin Microbiol 43:3944-55. doi: 10.1128/JCM.43.8.3944-3955.2005

52. Mardis ER (2011) A decade's perspective on DNA sequencing technology. Nature 470:198-203. doi: 10.1038/nature09796

53. Liu B, Faller LL, Klitgord N, et al (2012) Deep sequencing of the oral microbiome reveals signatures of periodontal disease. PLoS One 7:e37919. doi: 10.1371/journal.pone.0037919

54. Mardis ER (2008) The impact of next-generation sequencing technology on genetics. Trends Genet 24:133-41. doi: 10.1016/j.tig.2007.12.007

55. Décaillet F, Giannopoulou C, Cionca N, et al (2012) Microbial profiles of patients seeking treatment for periodontitis. Influence of origin, smoking and age? Schweiz Monatsschr Zahnmed 122:198-204.

56. Buchwald S, Kocher T, Biffar R, et al (2013) Tooth loss and periodontitis by socioeconomic status and inflammation in a longitudinal population-based study. J Clin Periodontol 40:203-11. doi: 10.1111/jcpe.12056

57. Lafaurie GI, Contreras A, Barón A, et al (2007) Demographic, clinical, and microbial aspects of chronic and aggressive periodontitis in Colombia: a multicenter study. J Periodontol 78:629-39. doi: 10.1902/jop.2007.060187

58. Kim TS, Kang NW, Lee S-B, et al (2009) Differences in subgingival microflora of Korean and German periodontal patients. Arch Oral Biol 54:223-9. doi: 10.1016/j.archoralbio.2008.10.005

59. Persson GR (2005) Site-based versus subject-based periodontal diagnosis. Periodontol 
2000 39:145-63. doi: 10.1111/j.1600-0757.2005.00130.x

60. Röder B, Frühwirth K, Vogl C, et al (2010) Impact of long-term storage on stability of standard DNA for nucleic acid-based methods. J Clin Microbiol 48:4260-2. doi: 10.1128/JCM.01230-10

61. Chapple ILC, Genco R, and on behalf of working group 2 of the joint EFP/AAP workshop. Diabetes and periodontal diseases: consensus report of the Joint EFP/AAP Workshop on Periodontitis and Systemic Diseases. J Clin Periodontol 2013; 40 (Suppl. 14): S106-S112. doi: $10.1111 /$ jcpe. 12077

62. Taylor JJ, Preshaw PM, Lalla E. A review of the evidence for pathogenic mechanisms that may link periodontitis and diabetes. J Clin Periodontol 2013; 40 (Suppl. 14): S113-S134. doi: $10.1111 /$ jcpe.12059. 
Table 1: Full Text Critical Appraisal Tables: Study Characteristics

\begin{tabular}{|c|c|c|c|c|c|}
\hline $\begin{array}{l}\text { Study \& study } \\
\text { type }\end{array}$ & $\begin{array}{l}\text { Participants: } \\
\text { 1. Total number } \\
\text { 2. Age range } \\
\text { 3. Drop-outs } \\
\text { 4. Source of recruitment } \\
\text { 5. Smoking habits } \\
\text { 6. Mean number of teeth } \\
\text { 7. Sites Assessed } \\
\end{array}$ & $\begin{array}{l}\text { Trial characteristics } \\
\text { 1. Location } \\
\text { 2. Number of centres } \\
\text { 3. Source of funding } \\
\text { 4. Ethical approval } \\
\text { 5. Year of trial conducted }\end{array}$ & Inclusion/exclusion criteria & $\begin{array}{l}\text { 1. Classification of DM } \\
\text { 2. Type of treatment carried out on } \\
\text { DM patients } \\
\text { 3. DM condition during study }\end{array}$ & $\begin{array}{l}\text { 1. Classification of periodontal status diagnosis } \\
\text { 2. Type of treatment carried out on } \\
\text { periodontitis patients } \\
\text { 3. Periodontal condition of dentition during } \\
\text { study }\end{array}$ \\
\hline $\begin{array}{l}\text { Collin et al. } \\
\text { (1998) } \\
\text { Case-control } \\
\text { study }\end{array}$ & $\begin{array}{l}\text { 1. } 65 \\
\text { 2. } 58 \text { to } 77 \text { years } \\
\text { 3. No } \\
\text { 4. Unclear } \\
\text { 5. } \mathrm{DM}=1 ; \mathrm{NDM}=2 \\
\text { 6. } \mathrm{DM}=13.2 ; \mathrm{NDM}=15.1 \\
\text { 7. } 4 \text { surfaces of each tooth for } \mathrm{PD}\end{array}$ & $\begin{array}{l}\text { 1. Kuopio, Eastern Finland } \\
\text { 2. One } \\
\text { 3. Unclear } \\
\text { 4. Yes } \\
\text { 5. } 1994\end{array}$ & $\begin{array}{l}\text { Exclusion: control subjects who had } \\
\text { developed diabetes as evidenced by } \\
\text { slightly elevated 2-hour plasma glucose } \\
\text { levels }\end{array}$ & $\begin{array}{l}\text { 1. Type } 2 \text { NIDDM, World Health } \\
\text { Organization (WHO) } \\
\text { 2. Unclear } \\
\text { 3. Type } 2 \text { NIDDM, }\end{array}$ & $\begin{array}{l}\text { 1. Mild or Advanced Periodontitis, based on bone } \\
\text { loss ( } 50 \% \text { cut-off) point and number of pockets } \\
\text { present } \\
\text { 2. N/A } \\
\text { 3. Mild or Advanced Periodontitis }\end{array}$ \\
\hline $\begin{array}{l}\text { Davila-Perez } \\
\text { et al. }(2007) \\
\text { Case-control } \\
\text { study }\end{array}$ & $\begin{array}{l}\text { 1. } 75 \\
\text { 2. Mean: G1- 42.7, G2-51.4, G3-49.1 } \\
\text { 3. No } \\
\text { 4. San Luis Potosi University and Hidalgo State } \\
\text { University, Mexico } \\
\text { 5. No } \\
\text { 6. Unclear } \\
\text { 7. all teeth }\end{array}$ & $\begin{array}{l}\text { 1. Mexico } \\
\text { 2. Two } \\
\text { 3. Unclear } \\
\text { 4. Yes } \\
\text { 5. 2004-2005 }\end{array}$ & $\begin{array}{l}\text { Exclusion: all subjects who received } \\
\text { professional cleaning, periodontal surgery } \\
\text { and antibiotic medication within } 3 \text { months } \\
\text { before the study }\end{array}$ & $\begin{array}{l}\text { 1. Type 2, American Diabetes } \\
\text { Association } \\
\text { 2. Unclear } \\
\text { 3. Type 2 }\end{array}$ & $\begin{array}{l}\text { 1. Chronic periodontitis, CAL and PPD with more } \\
\text { than } 5 \mathrm{~mm} \text { in at least } 10 \text { sites } \\
\text { 2. N/A } \\
\text { 3. Chronic periodontitis }\end{array}$ \\
\hline $\begin{array}{l}\text { Sardi et al. } \\
\text { (2011) } \\
\text { Case-control } \\
\text { study }\end{array}$ & $\begin{array}{l}\text { 1. } 20 \\
\text { 2. } 31 \text { to } 68 \text { years } \\
\text { 3. No } \\
\text { 4. Graduate Clinic of the Piracicaba Dental School, } \\
\text { State University of Campinas } \\
\text { 5. No } \\
\text { 6. Unclear } \\
\text { 7. at four sites per tooth for all teeth }\end{array}$ & $\begin{array}{l}\text { 1. Brazil } \\
\text { 2. One } \\
\text { 3. Brazil Government (CAPES) } \\
\text { 4. Yes } \\
\text { 5. Unclear }\end{array}$ & $\begin{array}{l}\text { Inclusion: generalised chronic } \\
\text { periodontitis, and healthy or controlled } \\
\text { type } 2 \text { DM } \\
\text { Exclusion: antibiotics and/or periodontal } \\
\text { treatment (last } 6 \text { months), pregnancy, } \\
\text { smoking, systemic disease, } \\
\text { immunosuppression, use of a partial } \\
\text { and/or total prosthesis, orthodontic } \\
\text { apparatus or any medication that could } \\
\text { affect the periodontium. }\end{array}$ & $\begin{array}{l}\text { 1. Controlled insulin-dependent type } \\
\text { 2 diabetes } \\
\text { 2. Unclear } \\
\text { 3. Controlled insulin-dependent type } \\
2 \text { diabetes }\end{array}$ & $\begin{array}{l}\text { 1. Severe Generalised chronic periodontitis } \\
\text { according to American Association of } \\
\text { Periodontology (1999) definition. } \\
\text { 2. N/A } \\
\text { 3. Severe Generalised chronic periodontitis, } \\
\text { untreated. }\end{array}$ \\
\hline $\begin{array}{l}\text { Ebersole et al. } \\
\text { (2008) } \\
\text { Case-control } \\
\text { study }\end{array}$ & $\begin{array}{l}\text { 1. } 63 \\
\text { 2. } 33 \text { to } 72 \text { years } \\
\text { 3. No } \\
\text { 4. University Health Centre } \\
\text { 5. NDM }=4 ; \mathrm{DM}=12 \\
\text { 6. Unclear } \\
\text { 7. Unclear }\end{array}$ & $\begin{array}{l}\text { 1. San Antonio, TX, USA } \\
\text { 2. One Centre } \\
\text { 3. University Health Centre and } \\
\text { US Public Health Service Grants } \\
\text { 4. Yes } \\
\text { 5.1994 }\end{array}$ & Unclear & $\begin{array}{l}\text { 1. American Diabetes } \\
\text { Association (1979) Criteria } \\
\text { 2. Unclear } \\
\text { 3. Type } 2 \text { (control status not } \\
\text { reported) }\end{array}$ & $\begin{array}{l}\text { 1. Periodontitis - at least three sites with probing } \\
\text { depths } \geq 6 \mathrm{~mm} \\
\text { 2. N/A } \\
\text { 3. Periodontitis, Untreated. }\end{array}$ \\
\hline
\end{tabular}




\begin{tabular}{|c|c|c|c|c|c|}
\hline $\begin{array}{l}\text { Ciantar et al } \\
\text { (2005) } \\
\text { Case-control } \\
\text { study }\end{array}$ & $\begin{array}{l}\text { 1. } 46 \\
\text { 2. } 35 \text { to } 65 \text { years } \\
\text { 3.No } \\
\text { 4. Periodontology Unit, Eastman Dental Hospital and } \\
\text { Diabetes Unit, Middlesex Hospital, London, U.K. } \\
\text { 5. DM=17; NDM =14 } \\
\text { 6. } \geq 20 \\
\text { 7. Unclear }\end{array}$ & $\begin{array}{l}\text { 1. London, UK } \\
\text { 2. } 2 \\
\text { 3. British Dental Association and } \\
\text { Eli Lilly Diabetes Research, UK } \\
\text { 4. Yes } \\
\text { 5. Unclear }\end{array}$ & $\begin{array}{l}\text { Inclusion: ages of } 35-65 \text { years; chronic } \\
\text { periodontitis, antibiotics or recent } \\
\text { Exclusion: } \\
\text { periodontal therapy, systemic conditions } \\
\text { requiring antibiotics complications; } \\
\text { infectious diseases; oral pathology other } \\
\text { than periodontitis; lactating or pregnant } \\
\text { females; dental restorations at or near } \\
\text { gingival margins or long-span dental } \\
\text { bridges; endocrine disorders other than } \\
\text { DM. }\end{array}$ & $\begin{array}{l}\text { 1. Type } 1 \text { and } 2 \text { DM } \\
\text { 2. Unclear } \\
\text { 3. Type } 1 \text { and } 2 \text { DM }\end{array}$ & $\begin{array}{l}\text { 1. Chronic periodontitis, Probing depth } \geq 5 \mathrm{~mm} \\
\text { and radiographic evidence of bone loss } \\
\text { 2. N/A } \\
\text { 3. Chronic periodontitis }\end{array}$ \\
\hline $\begin{array}{l}\text { Novaes et al. } \\
\text { (1997) } \\
\text { Case-control } \\
\text { study }\end{array}$ & $\begin{array}{l}\text { 1. } 60 \\
\text { 2. } 30 \text { to } 77 \text { years } \\
\text { 3. No } \\
\text { 4. Department of Neurology at University Hospital, } \\
\text { Periodontal Clinic of the School of Dentistry of the } \\
\text { Federal University of Rio de Janeiro } \\
\text { 5. Unclear } \\
\text { 6. Unclear } \\
\text { 7. } 6 \text { sites of each tooth }\end{array}$ & $\begin{array}{l}\text { 1. Brazil } \\
\text { 2. Two } \\
\text { 3. Unclear } \\
\text { 4. Unclear } \\
\text { 5. Unclear }\end{array}$ & $\begin{array}{l}\text { Inclusion: adult periodontitis; no } \\
\text { periodontal treatment for at least } 1 \text { year } \\
\text { before the initial examination and during } \\
\text { the study; no antibiotic administration } \\
\text { during the } 6 \text { months preceding } \\
\text { examination; no family history of diabetes } \\
\text { in the control patients. } \\
\text { Exclusion: Patients with an initial } \\
\text { diagnosis of localized juvenile } \\
\text { periodontitis or early onset periodontitis }\end{array}$ & $\begin{array}{l}\text { 1. Type } 2 \text { NIDDM } \\
\text { 2. Unclear } \\
\text { 3. Type } 2 \text { NIDDM }\end{array}$ & $\begin{array}{l}\text { 1. Unclear } \\
\text { 2. N/A } \\
\text { 3. Unclear }\end{array}$ \\
\hline 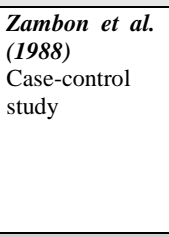 & $\begin{array}{l}\text { 1. } 55 \\
\text { 2. } 17 \text { to } 64 \text { years } \\
\text { 3. No } \\
\text { 4. Pima Indians of the Gila River Indian Community } \\
\text { south of Phoenix } \\
\text { 5. Unclear } \\
\text { 6. Unclear } \\
\text { 7. Unclear }\end{array}$ & $\begin{array}{l}\text { 1. AZ, US } \\
\text { 2. } 1 \\
\text { 3.Unclear } \\
\text { 4. Unclear } \\
\text { 5. Unclear }\end{array}$ & Unclear & 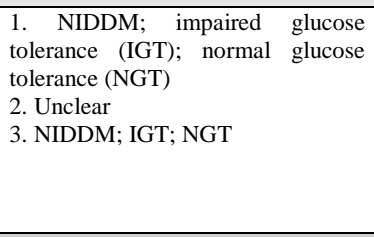 & $\begin{array}{l}\text { 1. Moderate to severe Periodontitis, Mean } \\
\text { interproximal PD }>5 \mathrm{~mm} \text {; Mean GI }>2 \text {; loss of } \\
25 \% \text { or more alveolar bone height } \\
\text { 2. N/A } \\
\text { 3. Moderate to severe Periodontitis }\end{array}$ \\
\hline $\begin{array}{l}\text { Christgau et } \\
\text { al. (1998) } \\
\text { Controlled } \\
\text { clinical trial }\end{array}$ & $\begin{array}{l}\text { 1. } 40 \\
\text { 2. } 30 \text { to } 67 \text { years } \\
\text { 3. No } \\
\text { 4. Endocrine Outpatients' Department, Department of } \\
\text { Internal Medicine I of the University of Regensburg; } \\
\text { Department of Operative Dentistry and } \\
\text { Periodontology of the University of Regensburg. } \\
\text { 5. NDM= } 6 \text { smokers; DM= } 4 \text { smokers } \\
\text { 6. Mean } 24 \\
\text { 7. } 4 \text { sites per tooth }\end{array}$ & $\begin{array}{l}\text { 1. Regensburg, Germany } \\
\text { 2. One } \\
\text { 3. Unclear } \\
\text { 4. Yes } \\
\text { 5. Unclear }\end{array}$ & $\begin{array}{l}\text { Inclusion: minimum age of } 30 \text { years; at } \\
\text { least } 16 \text { remaining teeth; moderate to } \\
\text { advanced periodontitis with bleeding or } \\
\text { pus on probing; at least } 6 \text { teeth with a } \\
\text { probing pocket depth of at least } 4 \mathrm{~mm} ; \text { no } \\
\text { evidence of systemic diseases other than } \\
\text { diabetes ; no antibiotic therapy within the } \\
\text { preceding } 6 \text { months; no need for antibiotic } \\
\text { prophylaxis }\end{array}$ & $\begin{array}{l}\text { 1. IDDM (insulin-dependent) and } \\
\text { NIDDM (non- insulin dependent) } \\
\text { 2. } 9 \text { subjects received insulin, } 8 \text { were } \\
\text { treated with oral anti-diabetic agents } \\
\text { and } 3 \text { were on diet. } \\
\text { 3. Median HbAlc values }\end{array}$ & $\begin{array}{l}\text { 1. Moderate to advanced periodontitis (with } \\
\text { bleeding or suppuration) } \\
\text { 2. a) oral hygiene instructions, supragingival } \\
\text { scaling, placement of emergency restorations, and } \\
\text { removal of overhanging cervical crown margins, } \\
\text { extractions of hopeless teeth, and splinting of } \\
\text { mobile teeth. } \\
\text { b) non-surgical periodontal therapy comprising } \\
\text { subgingival } \\
\text { scaling and root planning } \\
\text { 3. Moderate to advanced periodontitis }\end{array}$ \\
\hline $\begin{array}{l}\text { Field et al. } \\
\text { (2012) } \\
\text { Case-control } \\
\text { study }\end{array}$ & $\begin{array}{l}\text { 1. } 48 \\
\text { 2. }>35 \text { years }\end{array}$ & $\begin{array}{l}\text { 1. Newcastle, UK } \\
\text { 2. One centre }\end{array}$ & 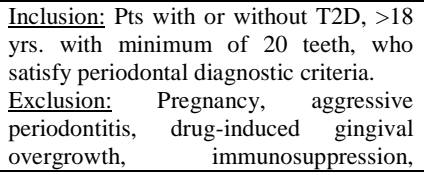 & $\begin{array}{l}\text { 1. T2D determined by physicians. } \\
\text { 2. N/A }\end{array}$ & $\begin{array}{l}\text { Active Chronic Periodontitis according to the } \\
\text { criteria proposed by the European Workshop of } \\
\text { Periodontology } 2005 \text { and the Centre for Disease } \\
\text { Control \& Prevention - American Academy of } \\
\text { Periodontology collaboration } 2007 \text {. } \\
\text { N/A }\end{array}$ \\
\hline
\end{tabular}




\begin{tabular}{|c|c|c|c|c|c|}
\hline & $\begin{array}{l}\text { 3. None reported } \\
\text { 4. Diabetes and Periodontitis clinic at Newcastle } \\
\text { Dental Hospital. } \\
\text { 5. T2D-PD: smokers 1: Non-smokers 8; T2D-non- } \\
\text { PD: 1:14; non-T2D-PD: 1:11; non-T2D-non-PD: } \\
\text { 0:12. } \\
\text { 6. Unclear } \\
\text { 7. } 3 \text { sites pooled from NPD. } 3 \text { shallow sites pooled } \\
\text { and } 3 \text { deepest sites ( } \geq 5 \mathrm{mmPPD} \text { ) pooled in PD. }\end{array}$ & $\begin{array}{l}\text { 3. Oral and Dental Research } \\
\text { Trust and the Newcastle } \\
\text { School of Dental Sciences } \\
\text { Research Committee. } \\
\text { 4. Obtained } \\
\text { 5. Unclear }\end{array}$ & $\begin{array}{l}\text { bleeding disorders, antibiotics in the last } \\
3 \text { months or nonsurgical periodontal } \\
\text { treatment in the previous } 6 \text { wks. }\end{array}$ & $\begin{array}{l}\text { 3. 'Stable' DM, defined by their } \\
\text { GP. HbAlc not recorded as a part } \\
\text { of this study. }\end{array}$ & $\begin{array}{l}\text { Unspecified other than 'active chronic } \\
\text { periodontitis'. }\end{array}$ \\
\hline $\begin{array}{l}\text { Zhou et al. } \\
\text { (2013) } \\
\text { Case-control } \\
\text { study }\end{array}$ & $\begin{array}{l}\text { 1. } 31 \\
\text { 2. } 30-65 \text { years } \\
\text { 3. None reported } \\
\text { 4. Unclear } \\
\text { 5. All non-smokers (at least } 3 \text { months) } \\
\text { 6. At least } 20 \text { teeth present. } \\
\text { 7. Unclear. }\end{array}$ & $\begin{array}{l}\text { 1. China } \\
\text { 2. One centre } \\
\text { 3. Government Research Grants, } \\
\text { and University Grants China and } \\
\text { USA. } \\
\text { 4. Obtained } \\
\text { 5. Unclear }\end{array}$ & $\begin{array}{l}\text { Inclusion: No usage of antibiotics or } \\
\text { NSAIDs, smoking in the previous } 3 \text { mo. } \\
\text { Had at least } 20 \text { teeth with no signs of oral } \\
\text { mucosal disease or root caries, no } \\
\text { previous periodontal treatments and age } \\
\text { range of } 30-65 \text { of age. } \\
\text { Exclusion: Pregnancy, HIV positive. }\end{array}$ & $\begin{array}{l}\text { 1. T2D, diagnosed for at least } 1 \text { year } \\
\text { with HbAlc } \geq 6.5 \% \text {, fasting plasma } \\
\text { glucose test } \geq 7.0 \mathrm{mmol} / \mathrm{L} \text {, or OGTT } \\
2 \mathrm{hr} \text { glucose test } \geq 11.1 \mathrm{mmo} / \mathrm{L} \text {. } \\
\text { 2. N/A } \\
\text { 3. Unclear }\end{array}$ & $\begin{array}{l}\text { Periodontitis, defined by: at least } 30 \% \text { of sites } \\
\text { with PPD and CAL, more than } 4 \text { with } P P D \geq 4 \mathrm{~mm} \\
\text { and } C A L \geq 2 \mathrm{~mm} \text {. } \\
\text { N/A } \\
\text { Unclear }\end{array}$ \\
\hline $\begin{array}{l}\text { Casarin et al. } \\
\text { (2013) } \\
\text { Case-control } \\
\text { study }\end{array}$ & $\begin{array}{l}\text { 1. } 23 \\
\text { 2. }>40 \text { years } \\
\text { 3. None reported } \\
\text { 4. Referrals to a Hospital or University Periodontal } \\
\text { Clinic. } \\
\text { 5. At least } 15 \text { teeth present }\end{array}$ & $\begin{array}{l}\text { 1. Brazil } \\
\text { 2. Two centres } \\
\text { 3. Grant FAPESP, no conflict of } \\
\text { interest. } \\
\text { 4. Yes } \\
\text { 5. July } 2007-\text { Feb } 2010 \text {. }\end{array}$ & $\begin{array}{l}\text { Inclusion: } \\
\text { Chronic periodontitis. } \\
\text { Uncontrolled T2D and age }>35 \text { yrs. } \\
\text { Exclusion: Pregnancy, lactation, } \\
\text { antibiotics required for treatment, } \\
\text { systemic diseases, and antibiotics in the } \\
\text { past } 3 \text { months, long-term anti- } \\
\text { inflammatories periodontal treatment in } \\
\text { the past } 6 \text { months. }\end{array}$ & $\begin{array}{l}\text { 1. Uncontrolled T2D. } \\
\text { 2. None. } \\
\text { 3. Uncontrolled. With } \\
\text { HbAlc }>8 \% \text {.HbAlc determined } \\
\text { using high-performance liquid } \\
\text { chromatography and fasting }\end{array}$ & $\begin{array}{l}\text { Chronic Periodontitis. American Association of } \\
\text { Periodontology (1999) definition. No treatment } \\
\text { group. } \\
\text { N/A } \\
\text { Chronic Periodontitis. Untreated }\end{array}$ \\
\hline
\end{tabular}




\begin{tabular}{|l|l|l|l|l|}
\hline & 6.5 sites per subject & & $\begin{array}{l}\text { plasma glucose determined using } \\
\text { the glucose oxidase method. }\end{array}$ \\
\hline
\end{tabular}


Table 2: Full Text Critical Appraisal Tables: Methodology Characteristics

\begin{tabular}{|c|c|c|c|c|}
\hline Study & Subgingival plaque (SP) collection method: & $\begin{array}{l}\text { Control vs Test group Division } \\
\text { 1. How they are divided } \\
\text { 2. Sample size calculation used? } \\
\text { 3. Non-DM periodontitis group vs T2D-PDgroup compared? } \\
\text { 4. Analysed according to different age range? What age range? }\end{array}$ & $\begin{array}{l}\text { Methods used to analyse bacteria. } \\
\text { 1. Culturing technique described. } \\
\text { 2. PCR technique described } \\
\text { 3. qPCR technique described } \\
\text { 4. ELISA } \\
\text { 5. Others }\end{array}$ & $\begin{array}{l}\text { 1. Confounding factors } \\
\text { considered. } \\
\text { 2. Number of bacteria analysed in } \\
\text { the study } \\
\text { 3. Number of non-bacteria } \\
\text { analysed. (yeast) }\end{array}$ \\
\hline $\begin{array}{l}\text { Collin et al. } \\
\text { (1998) }\end{array}$ & $\begin{array}{l}\text { SP samples obtained with a sterile curette from the } \\
\text { deepest pocket. }\end{array}$ & $\begin{array}{l}\text { 1. DM PD, NDM PD } \\
\text { 2. unclear } \\
\text { 3. yes } \\
\text { 4. no }\end{array}$ & PCR - I. Method described in original article and not here. & $\begin{array}{l}\text { 1. None. } \\
\text { 2. Three } \\
\text { 3. Zero }\end{array}$ \\
\hline $\begin{array}{l}\text { Davila-Perez et al. } \\
\text { (2007) }\end{array}$ & $\begin{array}{l}\text { SP samples obtained with a sterile Gracey curette } \\
\text { from the disto-lingual surface of the left } \\
\text { mandibular lateral incisor. }\end{array}$ & $\begin{array}{l}\text { 1. NDM NP, NDM PD, DM PD } \\
\text { 2. unclear } \\
\text { 3. yes } \\
\text { 4. no } \\
\end{array}$ & PCR assay, method described in article. & $\begin{array}{l}\text { 1. None. } \\
\text { 2. One (6 strains) } \\
\text { 3. Zero }\end{array}$ \\
\hline Sardi et al. (2011) & $\begin{array}{l}\text { SP samples obtained with a sterile periodontal } \\
\text { curette from the sites with the deepest } \mathrm{PD} \geq 5 \mathrm{~mm} \\
\text { and with furcation. }\end{array}$ & $\begin{array}{l}\text { 1. DM PD, NDM PD } \\
\text { 2. Unclear } \\
\text { 3. yes } \\
\text { 4. no } \\
\end{array}$ & PCR assay, method described in article. & $\begin{array}{l}\text { 1. None. } \\
\text { 2. Three } \\
\text { 3. One (4 strains) }\end{array}$ \\
\hline $\begin{array}{l}\text { Ebersole et al. } \\
\text { (2008) }\end{array}$ & $\begin{array}{l}\text { SP samples obtained with a modified } 1 / 2 \text { Gracey } \\
\text { curette from two healthy sites and two diseased } \\
\text { sites per subject. }\end{array}$ & $\begin{array}{l}\text { 1. NDM NPD, NDM PD, DM NPD, DM PD } \\
\text { 2. Unclear } \\
\text { 3. yes } \\
\text { 4. no }\end{array}$ & $\begin{array}{l}\text { DNA-DNA hybridization checkerboard procedure. Method } \\
\text { described in the article }\end{array}$ & $\begin{array}{l}\text { 1. Smoking } \\
\text { 2. } 14 \\
\text { 3. Zero }\end{array}$ \\
\hline $\begin{array}{lll}\text { Ciantar } & \text { et } & \text { al } \\
(2005) & & \end{array}$ & $\begin{array}{l}\text { SP samples obtained with a sterile Gracey curette } \\
\text { from three healthy and three diseased (deepest) } \\
\text { sites, inserting the curette to the full depth of the } \\
\text { pocket and subsequently moving it vertically along } \\
\text { the side of the root to the gingival margin. }\end{array}$ & $\begin{array}{l}\text { 1. DM PD, NDM PD } \\
\text { 2. Yes ( } 80 \% \text { chance of finding) } \\
\text { 3. yes } \\
\text { 4. no }\end{array}$ & Culture - Method described in the article & $\begin{array}{l}\text { 1. None. } \\
\text { 2. Seven } \\
\text { 3. Zero }\end{array}$ \\
\hline $\begin{array}{l}\text { Novaes et al. } \\
\text { (1997) }\end{array}$ & $\begin{array}{l}\text { SP samples obtained from the deepest pocket of } \\
\text { each quadrant }\end{array}$ & $\begin{array}{l}\text { 1. DM PD (controlled patients, moderately controlled patients, and } \\
\text { poorly controlled patients), NDM PD } \\
\text { 2. no } \\
\text { 3. yes } \\
\text { 4. no }\end{array}$ & BANA analysis - Method described in the article & $\begin{array}{l}\text { 1. None. } \\
\text { 2. Unclear } \\
\text { 3. N/A }\end{array}$ \\
\hline $\begin{array}{lll}\text { Zambon } & \text { et } & \text { al. } \\
(1988) & & \end{array}$ & $\begin{array}{l}\text { SP samples obtained using sterile paper points. } \\
\text { Three paper points were inserted to the depth of the } \\
\text { periodontal pocket. After ten seconds, the paper } \\
\text { points were removed. }\end{array}$ & $\begin{array}{l}\text { 1.NIDDM; IGT; NGT } \\
\text { 2. unclear } \\
\text { 3. yes } \\
\text { 4. no }\end{array}$ & $\begin{array}{l}\text { Culture. Method described in the article } \\
\text { Immunofluorescence and Microscopic Examination were } \\
\text { also done. }\end{array}$ & $\begin{array}{l}\text { 1. None. } \\
\text { 2. Three } \\
\text { 3. Zero }\end{array}$ \\
\hline $\begin{array}{l}\text { Christgau et al. } \\
\text { (1998) }\end{array}$ & $\begin{array}{l}\text { SP samples obtained using two ISO } 40 \text { sterile paper } \\
\text { points from the deepest periodontal pocket of each } \\
\text { of the } 4 \text { quadrants. After } 20 \text { seconds samples were } \\
\text { immediately transferred into RTF. Samples were } \\
\text { pooled per subject. }\end{array}$ & $\begin{array}{l}\text { 1. DM PD, NDM PD } \\
\text { 2. Unclear } \\
\text { 3. yes } \\
\text { 4. no }\end{array}$ & Culture - Method described in the article & $\begin{array}{l}\text { 1. None } \\
\text { 2. Seven } \\
\text { 3. Zero }\end{array}$ \\
\hline
\end{tabular}




\begin{tabular}{|c|c|c|c|c|}
\hline Field et al. (2012) & $\begin{array}{l}\text { SP samples obtained using three sterile endodontic } \\
\text { paper points left in situ for } 10 \text { seconds. For NPD - } \\
3 \text { shallow sites were sampled \& pooled. For PD - } 3 \\
\text { shallow sites were pooled and } 3 \text { deepest sites were } \\
\text { pooled. Supragingival plaque was removed with } \\
\text { curettes first. }\end{array}$ & $\begin{array}{l}\text { 1. DM PD, DM NPD, NDM PD, NDM NPD. } \\
\text { 2. Unclear } \\
\text { 3. yes } \\
\text { 4. no }\end{array}$ & $\begin{array}{l}\text { Culture - Method described in the article } \\
\text { PCR - Method described in the article } \\
\text { qPCR- Method described in the article }\end{array}$ & $\begin{array}{l}\text { 1. None } \\
\text { 2. Three } \\
\text { 3. None }\end{array}$ \\
\hline Zhou et al. (2013) & $\begin{array}{l}\text { SP samples obtained with sterile Gracey curettes } \\
\text { from the } 4 \text { deepest sites of the molars and } \\
\text { transferred into } 200 \mu \mathrm{L} \text { of PBS for immediate } \\
\text { freezing at }-70^{\circ} \mathrm{C} \text {. }\end{array}$ & $\begin{array}{l}\text { 1. NDM NPD, NDM PD, DM-NPD, DM-PD. } \\
\text { 2. Unclear } \\
\text { 3. yes } \\
\text { 4. } 30-65 \text {, analysis did not adjust for age. }\end{array}$ & 454 pyrosequencing - Method described in the article & $\begin{array}{l}\text { 1. Unclear } \\
\text { 2. Whole microbiome } \\
\text { 3. No }\end{array}$ \\
\hline $\begin{array}{lll}\begin{array}{l}\text { Casarin } \\
(2013)\end{array} & \text { et } & \text { al. }\end{array}$ & $\begin{array}{l}\text { SP samples obtained with sterile paper points } \\
\text { inserted into the bottom of the } 5 \text { chosen periodontal } \\
\text { pockets for } 30 \text { seconds before transferring to a tube } \\
\text { containing } 300 \mu \mathrm{L} \text { of reduced transport fluid. } \\
\text { Samples were pooled per subject. }\end{array}$ & $\begin{array}{l}\text { 1. DM PD, NDM PD } \\
\text { 2. Unclear } \\
\text { 3. yes } \\
\text { 4. Unclear }\end{array}$ & Sequencing - Method described in the article & $\begin{array}{l}\text { 1. Unclear } \\
\text { 2. Whole microbiota sequenced } \\
\text { 3. None }\end{array}$ \\
\hline
\end{tabular}


Table 3: Full Text Critical Appraisal Tables: Outcome Characteristics

\begin{tabular}{|c|c|c|c|}
\hline Study & Bacteria/ Yeasts reported & $\begin{array}{l}\text { Statistically significant results: } \\
\text { 1. What bacteria had different result inT2D PD compared to NT2D PD group? } \\
\text { 2. Description of the result }\end{array}$ & $\begin{array}{l}\text { Non-statistically significant results: } \\
\text { 1. What bacteria had different results inT2D PD compared to NT2D PD group? } \\
\text { 2. Description of the result }\end{array}$ \\
\hline Collin et al. (1998) & $\begin{array}{l}\text { P. gingivalis, } \\
\text { T. forsythia, } \\
\text { A. actinomycetemcomitans }\end{array}$ & $\begin{array}{l}\text { 1. } P . \text { gingivalis }(p=0.03) \\
\text { 2. DM- } P \text {. gingivalis detected in } 16.6 \% \text { of subjects } \\
\text { NDM- } P \text {. gingivalis detected in } 48.3 \% \text { of subjects }\end{array}$ & $\begin{array}{l}\text { 1. A. actinomycetemcomitans, T. forsythia } \\
\text { 2. DM- A. actinomycetemcomitans detected in } 8.3 \% \text { of subjects; T. forsythia detected } \\
\text { in } 71 \% \text { of subjects } \\
\text { NDM- A. actinomycetemcomitans detected in } 12.9 \% \text { of subjects; T. forsythia } \\
\text { detected in } 83.9 \% \text { of subjects }\end{array}$ \\
\hline Davila-Perez et al. (2007) & $\begin{array}{l}\text { P. gingivalis fimA genotypes } \\
\text { (I, Ib, II, III, IV, V) }\end{array}$ & $\begin{array}{l}\text { 1. } P \text {. gingivalis fimA genotype I } \\
\text { 2. } P \text {. gingivalis fimA genotype I statistical significance in total distribution between NDM NPD } \\
\text { (G1) and NDM PD (G2) (p=0.03) or NDM NPD (G1) and DM PD (G3) ( } p=0.03)\end{array}$ & $\begin{array}{l}\text { 1. P. gingivalis fimA genotypes } \\
\text { ( Ib, II, III, IV, V) } \\
\text { 2. In the groups } \mathrm{G} 2 \text { and } \mathrm{G} 3 \text { the distribution of types I and III fimA were more prevalent } \\
\text { in } \mathrm{G} 3 \text { patients but this did not reach statistical significance. }\end{array}$ \\
\hline Sardi et al. (2011) & $\begin{array}{l}\text { A. actinomycetemcomitans } \\
\text { P. gingivalis } \\
\text { T. forsythia } \\
\text { C. albicans, } \\
\text { C. dublinienses, } \\
\text { C. glabrata } \\
\text { C. tropicalis. }\end{array}$ & $\begin{array}{l}\text { 1. T. forsythia, C. albicans, C. dublinienses, C. glabrata and C. tropicalis. } \\
\text { 2. The prevalence of T. forsythia was statistically significantly less }(p<0.01) \text { in the biofilm of DM } \\
\text { compared to NDM subjects. } \\
\text { The prevalence of C. albicans, } C \text {. dublinienses, } C \text {. glabrata and C. tropicalis was statistically } \\
\text { signigficnalty more in the bifofilm of DM compared to NDM subjects }(p<0.05 \text { and } p<0.01, p<0.01 \text {, } \\
p<0.01, p<0.01 \text { respectively) }\end{array}$ & $\begin{array}{l}\text { 1. } P \text {. gingivalis, A. actinomycetemcomitans } \\
\text { 2. The prevalence of } P \text {. gingivalis was similar between the groups. The frequency of } \\
\text { A. actinomycetemcomitans was variable in the different periodontal sites, for both } \\
\text { groups. }\end{array}$ \\
\hline Ebersole et al. (2008) & $\begin{array}{l}\text { P. gingivalis, T. forsythia; } \\
\text { A. actinomycetemcomitans } \\
\text { P. intermedia, Eubacterium } \\
\text { spp., Veillonela parvula } \\
\text { Actinomyces spp., } \\
\text { Streptococcus spp. } \\
\text { Capnocytophaga spp. } \\
\text { Treponema denticola } \\
\text { Prevotella nigrescens, } \\
\text { Campylobacter } \text { spp. } \\
\text { Fusobacterium spp, } \\
\text { Selenomonas noxia } \\
\end{array}$ & $\begin{array}{l}\text { 1. P. gingivalis, Campylobacter } \mathrm{spp}, \text { A. actinomycetemcomitans. } \\
\text { 2. P. gingivalis, Campylobacter } \mathrm{spp} \text {. and A. actinomycetemcomitans were present in a significantly } \\
\text { greater proportion in PD DM versus PD NDM sites }(p<0.05) \text {. }\end{array}$ & $\begin{array}{l}\text { 1. T. forsythia, T.denticola, Eubacterium spp., P. nigrescens, S. noxia, P. } \\
\text { Intermedia, Fusobacterium spp., Actinomyces spp., Streptococcus spp., } \\
\text { Capnocutophaga spp. } \\
\text { 2. T. forsythia, T.denticola, Eubacterium spp., P. nigrescens, S. noxia, P. Intermedia } \\
\text { were present in a higher proportion in the PD DM versus the PD NDM group, } \\
\text { however the difference did not reach statistical significance. } \\
\text { Fusobacterium spp., Actinomyces spp., Streptococus spp., Capnocutophaga spp. } \\
\text { were present in a higher proportion in the PD NDM versus the PD DM group, } \\
\text { however the difference did not reach statistical significance. }\end{array}$ \\
\hline Ciantar et al (2005) & $\begin{array}{l}\text { C. gingivalis, } \\
\text { C. gingivalis variant, } \\
\text { C. ochracea, } \\
\text { C. ochracea variant, } \\
\text { C. sputigena, } \\
\text { C. granulosa, } \\
\text { C. haemolytica } \\
\text { Total anaerobic count }\end{array}$ & & $\begin{array}{l}\text { 1. In mixed T1 and T2 DM TCapno (total Caphnocytophaga), Total Anaerobic } \\
\text { Count (TAC), } \\
2 \text {. In mixed T1 and T2 DM TCapno comparison between the DM and NDM- PD } \\
\text { groups showed no significant difference among the diseased sites }(p=0.135 \text { ). } \\
\text { TAC comparison between the DM PD and NDM PD groups revealed only a } \\
\text { borderline significant difference among the diseased sites }(p=0.084) \text {. }\end{array}$ \\
\hline Novaes et al. (1997) & Unclear & $\begin{array}{l}\text { Correlating the subdivided DM groups (controlled, moderately controlled and poorly controlled) } \\
\text { and the NDM in terms of probing depths and BANA scores, a statistical significance }(p<0.05) \text { was }\end{array}$ & $\begin{array}{l}\text { Correlation between the DM PD and NDM PD in terms of different probing depths } \\
\text { and BANA scores, no statistical significance was found }(p>0.05) \text {. Correlating the } \\
\text { subdivided DM PD groups (controlled, moderately controlled and poorly controlled) }\end{array}$ \\
\hline
\end{tabular}




\begin{tabular}{|c|c|c|c|}
\hline & & $\begin{array}{l}\text { detected for 4-mm pockets in the poorly controlled patients and 5-, 6-, and 7-mm pockets for all } \\
\text { subdivisions. }\end{array}$ & $\begin{array}{l}\text { and the NDM PD group (control) in terms of probing depths and BANA scores, no } \\
\text { statistical significance was observed ( } p>0.05 \text { ) in the } 4-\mathrm{mm} \text { pockets of the controlled } \\
\text { and moderately controlled groups; }\end{array}$ \\
\hline Zambon et al. (1988) & $\begin{array}{l}\text { Bacteroides intermedius } \\
\text { Bacteroides gingivalis } \\
\text { Haemophilus. } \\
\text { actinomycetemcomitans }\end{array}$ & Statistical results for subgingival samples were not stated but the $\%$ of each bacteria. & $\begin{array}{l}\text { 1. Differences not tested statistically in } B \text {. intermedius and B. gingivalis. } \\
\text { 2. The proportion of } B \text {. gingivalis but not } B \text {. intermedius is higher in DM PD than in } \\
\text { other groups. NDM PD patients had significantly elevated levels of serum IgG toward } \\
B \text {. intermedius strain } 9336 \text {. }\end{array}$ \\
\hline Christgau et al. (1998) & $\begin{array}{l}\text { A. actinomycetemcomitans } \\
\text { P. gingivalis } \\
\text { P. intermedia } \\
\text { E. corrodens } \\
\text { F. nucleatum } \\
\text { P. micros } \\
\text { Veillonella sputigena }\end{array}$ & Statistical results for subgingival samples were not stated. & 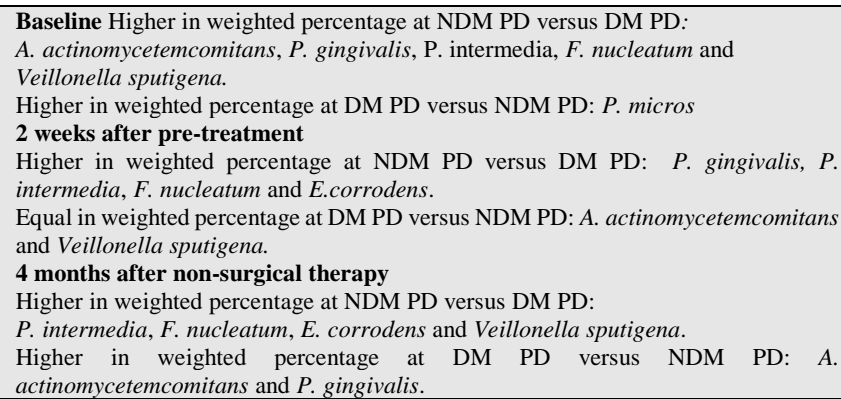 \\
\hline Field et al. (2012) & $\begin{array}{l}\text { P. gingivalis, } \\
\text { F. nucleatum, } \\
\text { A. actinomycetemcomitans. }\end{array}$ & $\begin{array}{l}\text { There were no statistically significant differences in the proportion of } P \text {. gingivalis, F. nucleatum } \\
\text { or A. actinomycetemcomitans found in the periodontal pockets in DM-PD patients when compared } \\
\text { with NDM PD patients }\end{array}$ & $\begin{array}{l}\text { 1. P. gingivalis, A. actinomycetemcomitans, F. nucleatum. } \\
\text { 2. P. gingivalis, proportions and log of total count found in the periodontal pockets } \\
\text { were lower in DM-PD patients when compared with NDM PD patients but the } \\
\text { differences did not reach statistical significance. A. actinomycetemcomitans } \\
\text { proportions and log of total count found in the periodontal pockets were higher in } \\
\text { DM-PD patients when compared with NDM PD patients but the difference did not } \\
\text { reach statistical significance. } \\
F \text {. nucleatum proportions found in the periodontal pockets in DM-PD patients when } \\
\text { compared with NDM PD patients were higher and the log of total count lower but the } \\
\text { differences did not reach statistical significance }\end{array}$ \\
\hline Zhou et al. (2013) & Whole microbiome & $\begin{array}{l}\text { At the phylum level, both Actinobacteria }(\mathrm{p}=0.0013) \text { and Proteobacteria }(\mathrm{p}=0.041) \text { had } \\
\text { significantly higher abundance in DM PD, while Bacteroidetes was more abundant in NDM PD } \\
(\mathrm{p}=0.018) \text {. } \\
\text { At the genus level, Actinomyces }(\mathrm{p}=0.0057) \text { and Aggregatibacter }(\mathrm{p}=0.00037) \text { were more } \\
\text { abundant or prevalent in the DM PD } \\
\text { At the OUT level, six significantly different OTUs were detected between the DM PD and NDM } \\
\text { PD samples: OTU0015 (classified as Burkholderiales at the order level), OTU0046 (P. tannerae), } \\
\text { TU0016 (classified as Propionibacteriaceae at the family level), OTU0161 (Capnocytophaga } \\
\text { sputigena), TU0010 (T. forsythia) and OTU0343 (classified as Prevotellaceae at the family level). }\end{array}$ & $\begin{array}{l}\text { Among the healthy sites of DM and NDM patients, no clear differences were } \\
\text { identified. }\end{array}$ \\
\hline Casarin et al. (2013) & Whole microbiome & $\begin{array}{l}\text { On Phylum level percentages of total clones were significantly higher in NDM PD versus DM PD } \\
\text { in Bacteroidetes, Spirochaetes and Synergistetes }(p<0.0001) \text {. } \\
\text { On Phylum level percentages of total clones were significantly lower in NDM PD versus DM } \\
\text { PD in Actinobacteria, Deferribacteres and Proteobacteria }(p<0.0001) \text {, as well as Fusobacteria } \\
\text { and TM7 ( }(p<0.001)\end{array}$ & $\begin{array}{l}\text { 2. On Phylum level percentages of total clones were lower in NDM PD versus DM } \\
\text { PD in Firmicutes but this did not reach statistical significance. } \\
\text { DM subjects had higher, but not statistically significantly, percentage of total clones } \\
\text { Porphyromonas endodontalis/ Oral Taxon } 273 / \text { Clone BB13 (p=0.55), Rothia } \\
\text { dentocariosa ( } p=0.27) \text {, Capnocytophaga gingivalis }(p=0.20) \text { and Parvimonas micra } \\
(p=0.11) \text { than NDM patients. . }\end{array}$ \\
\hline
\end{tabular}




\begin{tabular}{|c|c|c|c|}
\hline & & & $\begin{array}{l}\text { On Genera level percentages of total clones were statistically highly detected in NDM PD versus } \\
\text { DM PD on Porphyromonas, Filifactor, Eubacterium, Synergistetes, Tannerella and Treponema } \\
(p<0.05) \\
\text { On Genera level percentages of total clones were statistically lower detected in NDM PD versus } \\
\text { DM PD on_TM7, Aggregatibacter, Neisseria, Gemella, Eikenella, Selenomonas, Actinomyces, } \\
\text { Capnocytophaga, } \\
\text { Streptococcus. }(p<0.05) \\
\text { DM subjobactlonella had higher percentage of total clones of Streptococcus mitis, Eikenella corrodens, } \\
\text { Veillonella dispar and Veillonella parvula }(p<0.05) \text { and } F . \text { nucleatum }(p=0.05) \text { than NDM } \\
\text { patients. } \\
\text { NDM patients had a higher percentage of total clones of P. gingivalis, T. forsythia, Filifactor } \\
\text { alocis and Synergistetes clone BH017 than DM. }(p<0.05)\end{array}$ \\
\hline
\end{tabular}


Appendix Table A: Methodological Quality of the studies on Selection, Comparability and Exposure
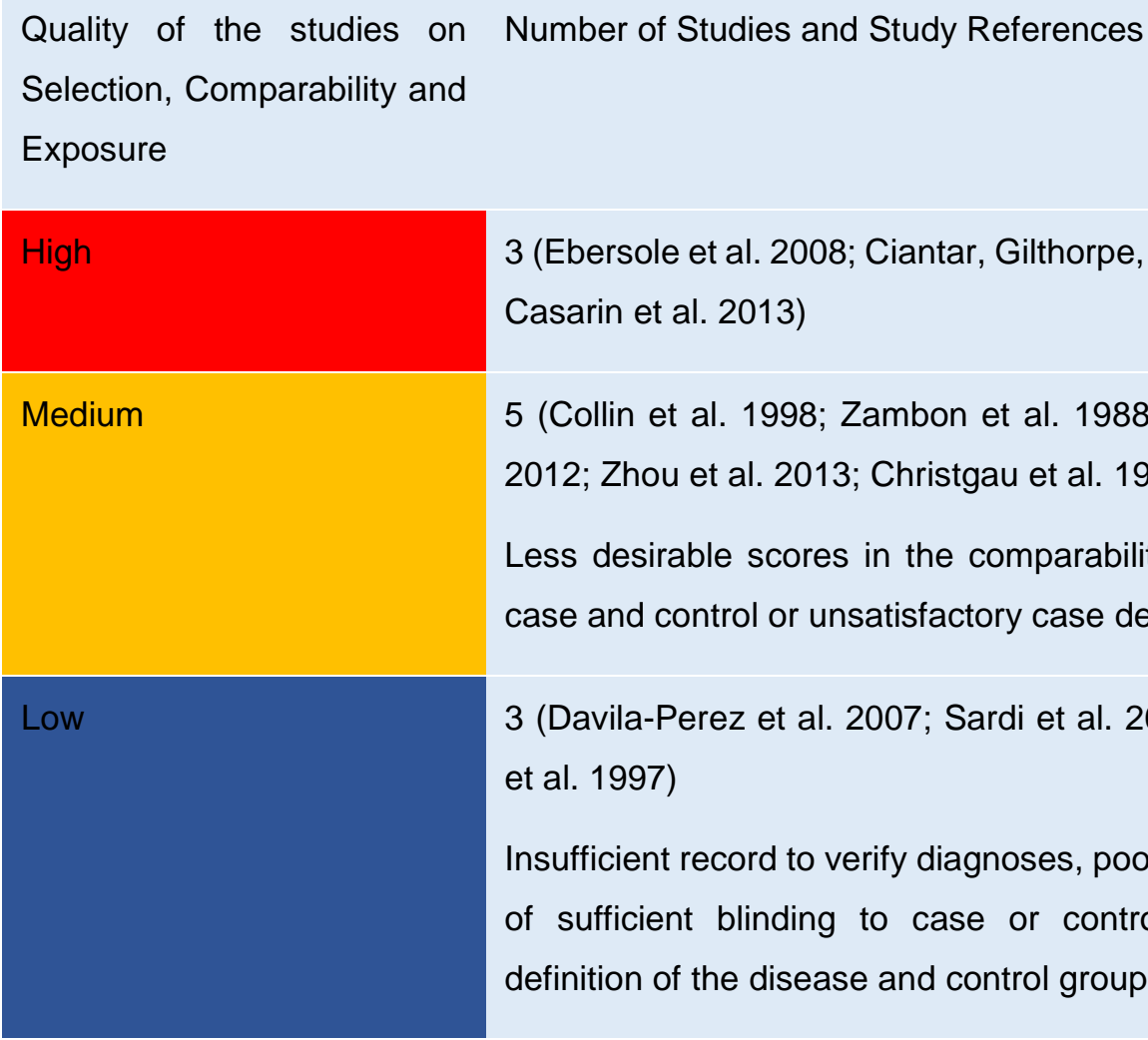

3 (Davila-Perez et al. 2007; Sardi et al. 2011; Novaes et al. 1997)

Insufficient record to verify diagnoses, poor statements of sufficient blinding to case or control and poor definition of the disease and control groups.

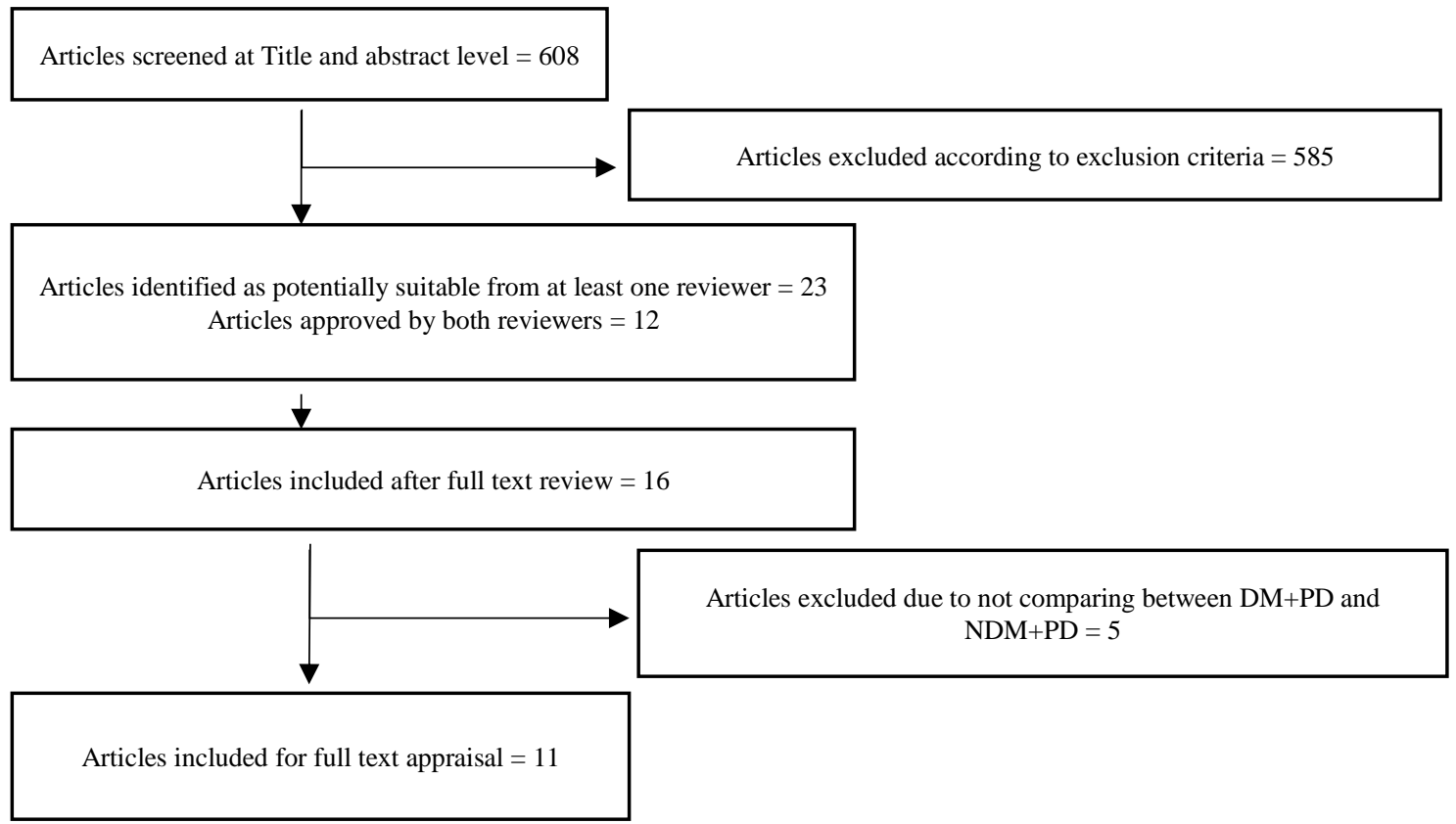


Figure 1: Summary of systematic review workflow. 